\title{
A geografia das exportações de produtos têxteis e de confecções no norte de Minas Gerais
}

\section{The geography of textile and clothing products exports in the north of Minas Gerais}

Luiz Andrei Gonçalves Pereira

Doutor em Geografia, professor do Departamento de Geociências e do Programa de Pós-Graduação em Geografia da

Universidade Estadual de Montes Claros, Brasil luizandreigoncalves@yahoo.com.br

Letícia Gonçalves Silva Santos Graduada em Geografia pela Universidade

Estadual de Montes Claros, Brasil

1goncalves197@gmail.com

\begin{abstract}
Resumo
A flexibilidade da produção e do consumo de produtos têxteis e de confecções ampliou as relações comerciais por meio das importações e exportações de insumos e de produtos acabados nos mercados globais. O objetivo deste artigo é analisar as dinâmicas espaciais das estruturas produtivas que viabilizaram as exportações de produtos têxteis e de confecções de empresas localizadas nos municípios da região norte de Minas Gerais, no período de 1997 a 2020. Na metodologia, utilizaram-se a revisão bibliográfica, a coleta e análise de dados secundários disponibilizados pelo Trad Map e pelo Comex Stat. Na (re)configuração espacial, focou-se no processo de surgimento, expansão, consolidação e de exportação de produtos das indústrias têxteis nos mercados mundiais. No norte de Minas Gerais, as exportações de produtos têxteis e de confecções se concentraram em oito municípios os quais conseguiram inserir os seus produtos nos mercados internacionais, principalmente dos Estados Unidos e Argentina.
\end{abstract}

Palavras-chave: Cadeia produtiva; exportações; indústria têxtil; indústria de confecções.

\begin{abstract}
The consumption of textile and clothing products and production expanded trade relations through imports and exports of inputs and finished products in global markets. This article aims to analyze the spatial dynamics of productive structures that made the textile and clothing products exports of companies from the North of Minas Gerais State between 1997 and 2020. The methodology workflow passed through bibliographic review and analysis of secondary data from Trad Map and Comex Stat. In the spatial (re)configuration, the focus was on the textile industry products emergence, expansion, consolidation, and exportation in world markets. In the North of Minas Gerais, exports of textile and clothing products were concentrated in eight municipalities, which managed to insert their products in international markets, mainly in the United States and Argentina.
\end{abstract}

Keywords: Productive chain; exports; textile industry; clothing industry. 


\section{INTRODUÇÃO}

A cadeia produtiva de produtos têxteis e de confecções é estratégica nos mercados nacionais e internacionais por demandar insumos de origens animal (lãs), vegetal (fibras) e de fibras sintéticas (artificiais) para a produção de fios e tecidos, que são utilizados em artigos de cama, mesa e banho, bem como na produção e confecções (roupas) que fazem parte do segmento de moda. Dessa forma, os insumos e os produtos acabados das indústrias têxteis e de confecções são comercializados pelas atuações dos agentes econômicos nos mercados globais por meio das interações socioespaciais das exportações e das importações.

As transformações tecnológicas e de gestão ocorridas nas companhias dos setores têxtil e de confecção contribuíram para o processo de fragmentação espacial das estruturas produtivas, visíveis historicamente na localização, deslocalização e relocalização das empresas em diferentes territórios, como forma de reduzir os custos operacionais e de garantir a competividade de seus produtos nos mercados internacionais, uma vez que as corporações especializaram as suas estruturas produtivas e suas redes de distribuição de mercadorias.

Em um cenário mundial de competividade dos negócios, as empresas do setor têxtil e de confecções instaladas na região norte de Minas Gerais receberam ou recebem os incentivos estatais e financeiros - regulamentados pelas políticas públicas de desenvolvimento regional -, especialmente da Superintendência do Desenvolvimento do Nordeste - SUDENE e do Banco do Nordeste do Brasil. Essas ações do poder público contribuíram para o processo de atração, de expansão e de modernização das estruturas produtivas das indústrias têxteis e de confecções que são competitivas com os seus diversos produtos nos mercados nacionais e internacionais. Na região norte-mineira, as empresas exportadoras dos segmentos têxteis e de confecções possuem um papel importante na dinâmica socioeconômica regional, principalmente na geração de empregos e renda, estando localizadas e concentradas nos municípios de Montes Claros, Pirapora, Espinosa, Taiobeiras, Salinas, Januária, Janaúba e Várzea da Palma.

O problema de estudo focou-se na seguinte questão: como se configura a rede de exportações das indústrias têxteis e de confecções na região norte de Minas Gerais? O objetivo deste artigo é analisar as dinâmicas espaciais das estruturas produtivas e dos fluxos das exportações de produtos têxteis e de confecções de empresas localizadas nos municípios norte-mineiros, no período de 1997 a 2020.

$\mathrm{Na}$ sistematização dos procedimentos metodológicos, a pesquisa foi desenvolvida por meio da pesquisa bibliográfica com foco na revisão de literatura para sustentar a abordagem teórica dos temas relacionados às estruturas produtivas e às exportações das indústrias têxteis e de confecções. Além 
disso, ocorreram a coleta, a tabulação e a organização dos dados oriundos da plataforma do Comex Stat, vinculada ao Ministério da Economia do Brasil, e do Trade Map. Os dados foram trabalhados por meio do uso de softwares Excel, versão 2010, e ARCGIS, versão 10.6.1, para a elaboração de materiais cartográficos (gráfico, tabela e mapa) que mostram os fluxos das exportações das indústrias têxteis e de confecções dos municípios do norte de Minas Gerais destinados aos mercados globais.

\section{A RECONFIGURAÇÃO TERRITORIAL E AS EXPORTAÇÕES DAS INDÚSTRIAS TÊXTEIS E DE CONFECÇÕES}

No campo da geografia industrial e da geografia comercial, a indústria têxtil teve reconhecidamente um papel fundamental no processo de industrialização que se consolida com a Primeira Revolução Industrial (século XVIII), por meio da produção de fibras/lãs, da geração de empregos e da comercialização de tecidos/confecções nos mercados nacionais e internacionais, pela Inglaterra, que foi pioneira nesse processo. Para chegar ao patamar de desenvolvimento e competitividade no qual se encontra, a indústria têxtil passou por diversos processos de transformações, sobretudo em segmentos tecnológicos que a colocaram como um dos setores mais dinâmicos na indústria mundial, devido à mecanização da estrutura de produção com as maquinarias, à organização da cadeia de insumos de fibras e lãs e à logística no processo de comercialização de produtos têxteis e vestuários (COMISSÃO EXECUTIVA TÊXTIL - CETEX, 1946).

Na evolução do setor têxtil, Lima e Oliveira Neto (2017) destacaram que, nos séculos XVII e XVIII, o crescimento populacional, mormente a partir da Revolução Industrial, alterou o padrão de consumo e elevou as demandas por mercadorias industrializadas no mercado interno. Posteriormente, os produtos industrializados se expandiram para os mercados externos, sobretudo em territórios coloniais que se tornaram novos mercados consumidores e fornecedores de matériasprimas, favorecendo a rede de comércio internacional inglesa.

A Revolução Industrial alterou a política comercial entre a Índia e a Inglaterra, uma vez que os ingleses deixaram de importar grandes quantidades de tecidos de algodão dos indianos e passaram importar o algodão bruto e processá-lo na indústria têxtil mecanizada, produzindo e exportando tecidos a preços mais competitivos (PEZZOLO, 2019). Na concepção de Hobsbawn (2010), a indústria têxtil inglesa aumentou a produção para atender a demanda dos mercados interno e externo em um cenário crescente das exportações de tecidos de algodão por meio do controle da estrutura produtiva e dos pontos estratégicos de escoamento dos produtos.

No contexto de expansão da indústria têxtil mundial, a Guerra de Secessão nos Estados Unidos, no século XVIII, desestabilizou a hegemonia e o crescimento da indústria têxtil inglesa, 
uma vez que, no território norte-americano, desenvolveu-se também a indústria têxtil e de maquinarias. Isso favoreceu o surgimento de regiões produtoras de algodão na Índia, Egito, Brasil, entre outros, para abastecer as indústrias norte-americanas. Consequentemente, esses países desenvolveram a indústria têxtil em seus territórios, inclusive importando máquinas dos Estados Unidos (CUNHA, 2018).

A indústria inglesa se expandiu e se consolidou no comércio internacional, uma vez que outros países (França, Alemanha, Estados Unidos, entre outros) entraram em disputas políticas e econômicas no segmento têxtil, instigando, também, as disputas pelos mercados coloniais para vender produtos manufaturados têxteis e comprar matérias-primas, como as fibras (ARRUDA, 2016). No século XIX, a indústria têxtil expandiu-se para outros países do mundo, com destaque para os Estados Unidos, França, Alemanha, Itália, Espanha, Japão, China, Rússia, Índia e Brasil, entre outros, reconfigurando a cadeia de produção e de comercialização de produtos têxteis (fios e tecidos) e de confecções (roupas) em mercados nacionais e internacionais (CETEX, 1946).

A atividade industrial têxtil transformou e sistematizou a estrutura de produção, ao readequar e inovar os seus processos produtivos. Até a segunda metade do século XX, o fordismo organizou os modos de produção pautados no aumento da produtividade, na produção e consumo em massa, na especialização da força de trabalho, no controle do tempo de produção, na diminuição do tempo para executar tarefas, no uso de máquinas na estrutura produtiva e na homogeneização dos produtos (FRAGA, 2006). Na era fordista, a indústria têxtil desenvolveu o seu processo produtivo com foco na competividade de seus produtos nos mercados, principalmente os nacionais que eram protegidos com barreiras comerciais.

$\mathrm{Na}$ abordagem de Fraga (2006), a estrutura de produção fordista, que era rígida, entrou em declínio em função das transformações tecnológicas que demandaram a flexibilidade na estrutura de produção, assim, as empresas passaram a incorporar as tecnologias de informação na sua (re)estruturação produtiva, sendo que, após a década de 1970, ocorreu a expansão da estrutura de consumo e de produção flexível. No Pós-fordismo, segundo Lal (2009), as corporações aplicaram mais conhecimento na cadeia de produção com foco no aumento da produtividade, na capacidade de inovação e na competividade de seus produtos. Dessa forma, as empresas visavam a maiores fatias dos mercados consumidores, por meio de redução de custos, de melhoria na qualidade, de maior diversidade, de menor prazo de entrega e de agregação de valores aos produtos.

Com a intensificação do processo de globalização, por meio de inovações tecnológicas que facilitaram a flexibilização da produção, atrelada à expansão do sistema financeiro, a reestruturação produtiva resultou em transformações nas atividades econômicas e nas formas de consumo. Nesse contexto, a indústria têxtil obteve as transformações tecnológicas que melhoraram o processo 
produtivo em termos de qualidade dos produtos, de incorporação de equipamentos modernos na linha de produção e de redução de custos dos produtos. As empresas que não se modernizaram tecnologicamente foram à falência ou foram compradas por empresas concorrentes. Por outro lado, as corporações que investiram no uso de tecnologia conseguiram sobreviver em um mercado cada vez mais competitivo (SARAIVA; PIMENTA; CORRÊA, 2005).

No processo de fragmentação da estrutura produtiva, as indústrias, em geral, reorganizaram as suas bases produtivas no espaço geográfico mundial ao se instalarem em lugares que disponibilizam incentivos para a manutenção e barateamento de custos, possibilitando a competividade. As indústrias têxteis e de confecções passaram por um processo de realocação das etapas de produção por meio da transferência de unidades para países cujo custo de mão de obra intensiva era baixo, além da oferta de energia barata, incentivos fiscais e financeiros, entre outros. A deslocalização dos processos produtivos favoreceu uma Nova Divisão Internacional do Trabalho, que estabeleceu a especialização produtiva e a redução de custos operacionais, visto que se tem o aumento da produtividade, competividade e lucratividade dos produtos (SCHEFFER, 1995).

$\mathrm{Na}$ reestruturação produtiva da cadeia têxtil e de confecções, principalmente a partir da década de 1970, as empresas localizadas nos países de maior complexidade industrial transferiram as suas unidades de produção para os países de menor complexidade industrial e se dedicaram a operacionalizar e controlar as atividades que demandavam conhecimentos especializados, terceirizando as atividades de produção nos países que apresentavam menores custos operacionais. A deslocalização da produção têxtil levou a mudanças na produção de confecções, visto que aumentava a terceirização e subcontratação de etapas dos processos produtivos no exterior. Nessa dinâmica econômica, aumentaram a comercialização por meio de exportações de insumos e de produtos (semi)acabados de produtos têxteis no mercado internacional (LAL, 2009).

Para Scheffer (1995), a integração na cadeia produtiva têxtil demanda uma inter-relação entre a fabricação de tecidos e de confecções, posto que se têm as reservas de mão de obra barata, as operações fragmentadas de processos produtivos, a redução dos custos e a agilidade dos transportes e das comunicações. Tudo isso permitiu a fragmentação da estrutura de produção por meio da deslocação de empresas do setor têxtil e confecções das economias centrais para as economias periféricas. A indústria têxtil tornou-se intensiva em capital e a indústria de confecções dependente de trabalho intensivo, assim, a (re)localização dessas atividades permitiu a redução de custos, o uso de tecnologia e a competitividade do setor têxtil e confecções, ampliando as inovações de produtos e as receitas financeiras por meio das exportações (KON; COAN, 2005).

$\mathrm{Na}$ cadeia produtiva da indústria têxtil, os principais insumos utilizados são as fibras naturais de origem vegetal (algodão e linho), os produtos de origem animal (lã e a seda) e os 
produtos de filamentos sintéticos originários da indústria petroquímica, entre os quais se destacam o poliéster, polipropileno, náilon e acrílico (MENDES JUNIOR, 2019). Apesar da expansão das fibras sintéticas nos mercados, segundo Pezzolo (2019), o uso mais popular e amplo na indústria têxtil é da fibra do algodão, por causa da sua versatilidade, no atendimento de demandas dos mercados consumidores.

A cadeia têxtil e de confecções incorpora a produção das fibras têxteis e engloba etapas dos processos de fiação (fios), tecelagem (tecidos) e beneficiamento do tecido na tinturaria, no alvejamento, estamparia, lavanderia, entre outros, incluindo o produto acabado e confeccionado. Outra etapa da produção têxtil é constituída por atividades da indústria de confecção de artigos ligados à fabricação de vestuários e de acessórios. Depois de fabricados, esses produtos são comercializados e distribuídos nos mercados nacionais e internacionais (MENDES JUNIOR, 2019).

$\mathrm{Na}$ (re)configuração territorial da indústria têxtil e de confecções mundial, Scheffer (1995), Lal (2009), Scheffer (2012) e Shishoo (2012) destacam que, até a década de 1980, a produção da indústria têxtil e de confecções estava concentrada no Estados Unidos, na Europa e no Japão. A partir desse período, verificou-se uma intensidade nas transformações das estruturas produtivas das grandes corporações que, em suas políticas de descentralização das unidades produtivas, redistribuíram espacialmente as indústrias têxteis e de confecções nos países em desenvolvimento da Ásia, do Leste Europeu, da África, da América Latina e Caribe. Nessa dinâmica, o continente asiático passou a receber e a concentrar grande parte da produção têxtil e de confecções, destacando-se países como a China, Índia, Paquistão, Coreia do Sul, Taiwan, Indonésia, Malásia, Tailândia, Bangladesh, entre outros.

$\mathrm{Na}$ estrutura comercial global que incorpora os países e/ou territórios, no período de 2001 a 2020, os dados da plataforma Trade Map mostram que a distribuição espacial da comercialização de produtos têxteis e de confecções concentrou na China, representando cerca de 30\% das exportações mundiais, sendo seguida por um grupo formado por 20 países que tiveram uma participação que variou de 1 a 5\%; os demais países individualmente tiveram uma participação nas exportações mundiais de produtos têxteis e de confecções menor que 0,9\% (Mapa 1). 
Mapa 1 - Comércio global de produtos têxteis e de confecções: exportações por países, acumulado no período de 2001 a 2020 (Valores em 1.000 US\$ e Percentuais)

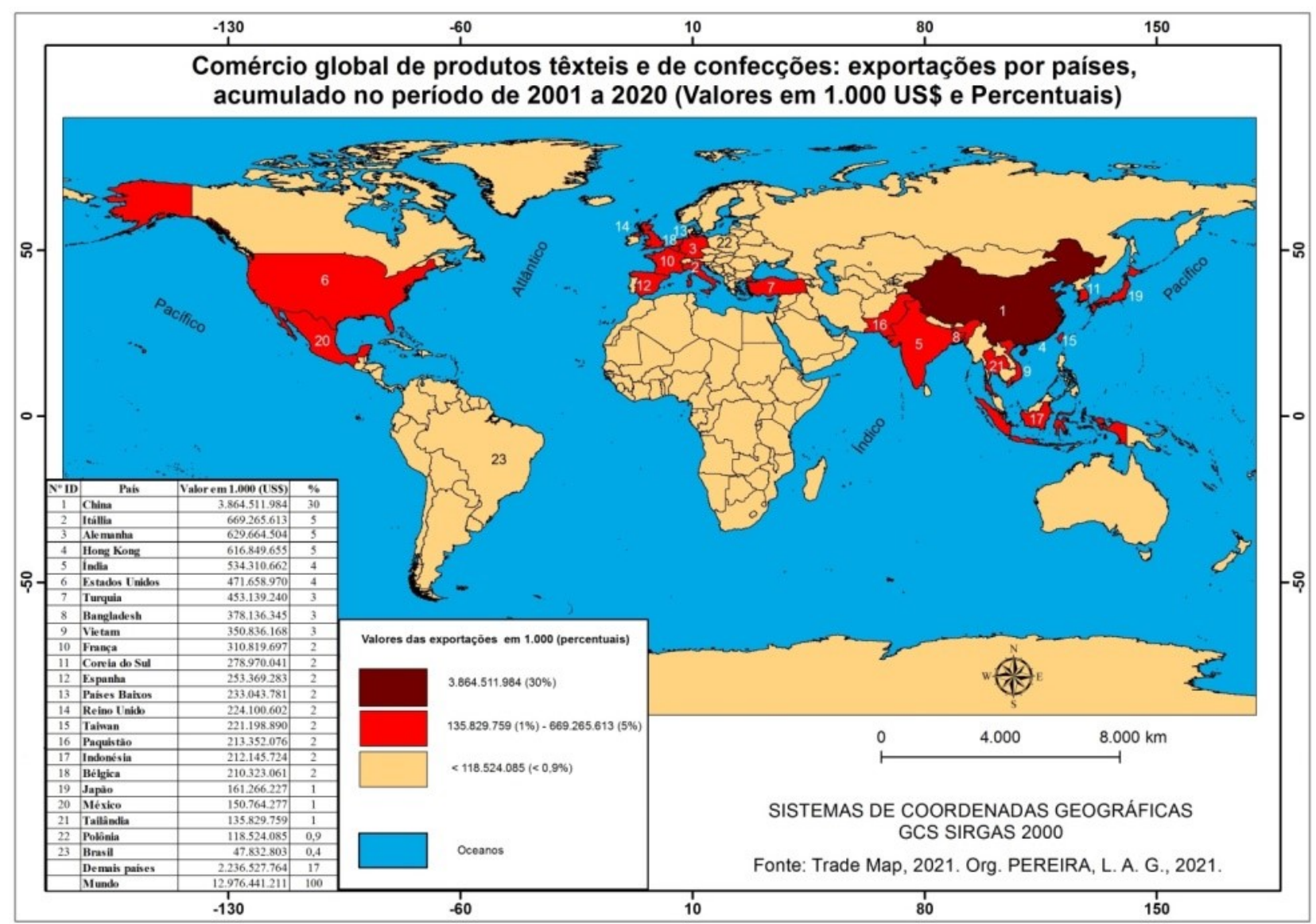

Fonte: Trade Map, 2021. Org. PEREIRA, L. A. G., 2021. Nota: O setor de produtos têxteis e de confecções foi organizado por meio da seção XI, matérias têxteis e suas obras, que incorpora os produtos do Sistema Harmonizado SH2 de número 50 a 63.

No mercado internacional de produtos têxteis e de confecções, a partir dos dados apresentados no Mapa 1, percebe-se uma monopolização de empresas chinesas nas exportações que foram beneficiadas com o fim do Acordo Multifibras (Multi-Fiber Arrangement - MFA). Para Lima (2009), em 1973, esse acordo foi criado com o intuito de impor medidas restritivas para viabilizar o ganho de competitividade das indústrias têxteis dos países desenvolvidos por meio da consolidação e da estruturação de suas indústrias. As medidas implantadas restringiram a participação de indústrias têxteis localizadas nos países em desenvolvimento nas exportações.

As pressões e as negociações foram constantes em prol da suspensão das medidas restritivas, assinando os acordos comerciais de cunho mais liberal que viabilizassem participação maior de empresas do setor têxtil e de confecções localizadas nos países em desenvolvimento no comércio global por meio de exportações. Em 1995, passou a vigorar o Acordo sobre Têxteis e Vestuário (ATV), substituindo de forma gradual o Acordo Multifibras e representando uma fase de transição na liberalização dos mercados de produtos têxteis e de vestuário. Em 2005, o Acordo sobre Têxteis e Vestuário (ATV), encerrou-se e entraram em vigor as normativas de cunho liberal por meio da 
remoção de barreiras comerciais, em um cenário de multilateralização do comércio global, o que contribuiu para a ampliação da participação de empresas têxteis e de confecções localizadas na Ásia nos mercados internacionais. (LIMA, 2009; COSTA, ROCHA, 2009).

É importante enfatizar que as indústrias têxteis e de confecções vivenciaram um processo intenso de transformações e de inovações em suas bases produtivas para serem competitivas nos mercados nacionais e internacionais. Nesse cenário, na seção seguinte, focou-se na indústria têxtil e de confecções no Brasil com a finalidade de compreender a inserção de suas exportações nos mercados globais.

\section{A (RE)CONFIGURAÇÃO TERRITORIAL DA PRODUÇÃO E DAS EXPORTAÇÕES DE PRODUTOS TÊXTEIS E DE CONFECÇÕES NO BRASIL}

No século XIX, iniciou-se o processo de implantação e de expansão da indústria têxtil no território brasileiro. Conforme Stein (1979), em 1844, a indústria têxtil surgiu de forma pioneira na Bahia em razão da disponibilidade de matéria-prima, de fontes de energia, de mercados consumidores (rurais e urbanos) e de transportes (marítimo e fluvial), que eram usados na movimentação de matérias-primas, de maquinarias e de produtos voltados para atender a indústria têxtil. Então, depois da década de 1860, intensificou-se a expansão da indústria têxtil brasileira.

Nas palavras de Suzigan (2000), no período de 1860 até 1873, houve o primeiro surto de expansão da indústria têxtil no Brasil em um cenário de valorização da moeda (Réis), que contribuiu para a queda do preço dos bens de capital importados (máquinas) utilizados na fabricação de tecidos. Já na década de 1880, ocorreu o segundo surto da indústria têxtil brasileira, com o surgimento de 47 novas fábricas, também ocorreu a expansão das indústrias têxteis existentes. Segundo Stein (1979), em 1885, a configuração territorial do setor têxtil se concentrava em Minas Gerais, seguido por Bahia, Rio de Janeiro e São Paulo, nessa ordem.

A partir de 1890, os industriais pressionaram o governo brasileiro a intervir de forma mais rígida na proteção e no estímulo ao setor por meio da implantação e da elevação de medidas tarifárias protecionistas para importações de produtos têxteis (ALBUQUERQUE, 1982). Nesse contexto de proteção à indústria nacional, segundo Clementino (2012), os empresários adquiriram novas maquinarias que foram instaladas nas fábricas têxteis, ampliando a capacidade produtiva, principalmente para atender o mercado interno.

No processo de inserção de produtos têxteis fabricados no Brasil em mercados internacionais, segundo Clementino (2012), no período de 1917 a 1923, a indústria têxtil brasileira exportou produtos para os mercados da África do Sul e da Argentina. Mas, com a crise de 1929, o setor foi afetado e a retomada de crescimento ocorreu com a Segunda Guerra Mundial, momento 
em que os países sul-americanos tiveram interrupção nas importações inglesas, japonesas e recorreram à indústria têxtil brasileira para o suprimento de seus mercados (CETEX, 1946).

No contexto da Segunda Guerra Mundial, Fujita e Jorente (2015) destacam que os países fornecedores de produtos têxteis nos mercados internacionais se dedicaram a outros ramos industriais, principalmente o militar. Nesse cenário, o Brasil tornou-se o segundo maior produtor de têxteis e aumentou a sua exportação em 15 vezes no abastecimento de mercados da América Latina, Europa e Oriente Médio (STEIN, 1979). Segundo a CETEX (1946), o bom desempenho do setor têxtil favoreceu a importação de máquinas modernas para aumentar a produtividade e a competividade da indústria têxtil brasileira.

No período de 1950 a 1980, ocorreu o auge da política industrial brasileira na fase da indústria de substituição de importações, que passou a estimular por meio de incentivos e subsídios a produção de bens para atender o mercado nacional. Isso favoreceu o desenvolvimento da indústria local, restringiu as importações de produtos e provocou um isolamento comercial. No final da década de 1970, houve um tímido processo de modernização produtiva, o que não possibilitou uma melhoria significativa na organização do trabalho e na aquisição de equipamentos microeletrônicos, uma vez que, no mundo, essa década foi um marco na inserção da microeletrônica na atividade industrial, o que resultou em inovações tecnológicas na estrutura produtiva pós-fordista (SARAIVA; PIMENTA; CORRÊA, 2005).

Para Massuda (2002), na década de 1980, o saldo da balança comercial têxtil foi positivo devido às políticas de incentivos às exportações e às restrições de importações. Segundo Campos e Paula (2006), a proteção do mercado interno brasileiro associada à estagnação econômica não fomentaram os investimentos em tecnologia de ponta e sucatearam o setor têxtil. No entanto, Lisboa (2013) destacou que, nessa década, ocorreu a consolidação do setor têxtil - uma vez que não se exigiram altos investimentos de capital - o que propiciou um retorno mais rápido, em razão da estrutura produtiva disponível e do consumo garantido pelo fechamento do mercado interno brasileiro.

Na década de 1990, a abertura comercial brasileira trouxe transformações significativas na indústria têxtil e de confecções brasileira, visto que a estabilização da moeda pelo Plano Real e a suspensão de barreiras comerciais provocaram o aumento nos investimentos em modernização da estrutura produtiva por meio da importação de equipamentos, o que aumentou a competividade e rompeu com o isolamento no mercado externo (GORONI, 2000). A modernização do parque industrial têxtil ocorreu com as importações de produtos, de máquinas e de equipamentos, que reestruturaram a base produtiva, uma vez que reduziram o número de empresas e de empregos (MASSUDA, 2002). Para Campos e Paula (2006), no cenário de rápida abertura comercial, a 
reestruturação do setor têxtil não atingiu todas as empresas, pois muitas delas não conseguiram se ajustar às novas exigências de modernização, dessa forma, as empresas que não se modernizaram faliram e as que se modernizaram sobreviveram em um mercado competitivo.

As empresas têxteis e de confecções brasileiras, com estrutura produtiva moderna, tiveram fragilidades diante da competividade das importações de produtos têxteis oriundos de países asiáticos - grandes produtores e exportadores - dada a valorização cambial. A partir de 1998, houve uma recuperação da competividade da indústria têxtil brasileira devido à desvalorização cambial em relação ao dólar norte-americano que encareceu os valores dos produtos têxteis importados no mercado brasileiro. Então, a indústria têxtil se posiciona de forma razoável no mercado internacional influenciada pela qualidade e pelos preços competitivos dos produtos (KON; COAN, 2005). Na concepção de Lisboa (2013), um fator importante que alavancou as exportações de produtos têxteis e de confecções de origem brasileira foi o crescimento do comércio intrabloco econômico, especialmente no Mercado Comum do Sul - MERCOSUL. A redução de barreiras comerciais entre os países membros desse bloco propiciou uma maior integração de artigos têxteis e confecções que, em um ambiente de concorrência internacional, demandou reorganização na estrutura produtiva.

Nos anos 2000, houve um aumento no crescimento do consumo mundial de têxteis e de confecções com uma participação expressiva de produtos chineses no comércio internacional, principalmente, por causa da valorização cambial do Real e do fim do Acordo de Têxteis e Vestuários (ATV) em 2005, observa-se perda de competitividade de produtos têxteis de origem brasileira, que tiveram queda na participação das exportações destinadas aos mercados globais (COSTA; ROCHA, 2009). Na concepção de Filleti e Boldrin (2020), a valorização do Real encareceu os custos dos têxteis e de confecções de origem brasileira nos mercados internacionais e barateou os preços dos têxteis e confeccionados importados, especialmente oriundos dos países asiáticos, com destaque para a China.

A crise global de 2008 - que foi originada no mercado norte-americano no segmento imobiliário e financeiro de alto risco (subprime), provocando a falência de instituições financeiras e gerando turbulências nos mercados internacionais - afetou também a indústria têxtil e de confecções brasileira, visto que a competitividade da indústria chinesa favoreceu a expansão de seus produtos no mercado brasileiro (BORÇA JUNIOR; TORRES FILHO, 2008; LISBOA, 2013). Para Mendes Junior (2019), em 2015, a queda de produtos dos segmentos têxteis foi mais expressiva em empresas que atuavam nas áreas de fiação e malharias. Dessa forma, a China passou a ser o maior produtor e exportador de produtos têxteis e vestuários no mundo, e, para atender essas demandas de 
produção, passou a importar matérias-primas, destacando-se o algodão/fibras (FILLETI, BOLDRIN, 2020).

A indústria têxtil brasileira perdeu competitividade nos mercados internacionais para as exportações, após sofrer com a concorrência dos produtos importados no mercado nacional. Destaca-se que o Brasil possui uma importante indústria têxtil e de confecções, mas uma parte expressiva da sua produção está voltada para o mercado interno (LISBOA, 2013). O país teve uma participação de aproximadamente $0,4 \%$ das exportações mundiais, ao considerar a evolução das exportações de materiais têxteis e de confecções em valores financeiros.

O Gráfico 1 mostra que, no período de 1997 a 2020, ocorreu uma queda constante nas exportações de produtos têxteis e de confecções, retomando o crescimento em 2000 e 2001; em 2002, apresentou novamente queda nas exportações. No período de 2003 a 2005, o crescimento foi constante; em 2006, voltou a cair, mas retomou o crescimento em 2007 e 2008. Em 2009, caiu novamente, mas aumentou de forma acentuada de 2010 a 2012; em 2013, acabou apresentando uma forte queda; em 2014, teve um leve aumento, mas reduziu seu desempenho nos dois anos seguintes e teve um crescimento significativo a partir de 2017.

Gráfico 1 - Exportações de matérias têxteis e de confecções no Brasil, no período de 1997 a 2020 (Valores em bilhões US\$/F.O.B.)

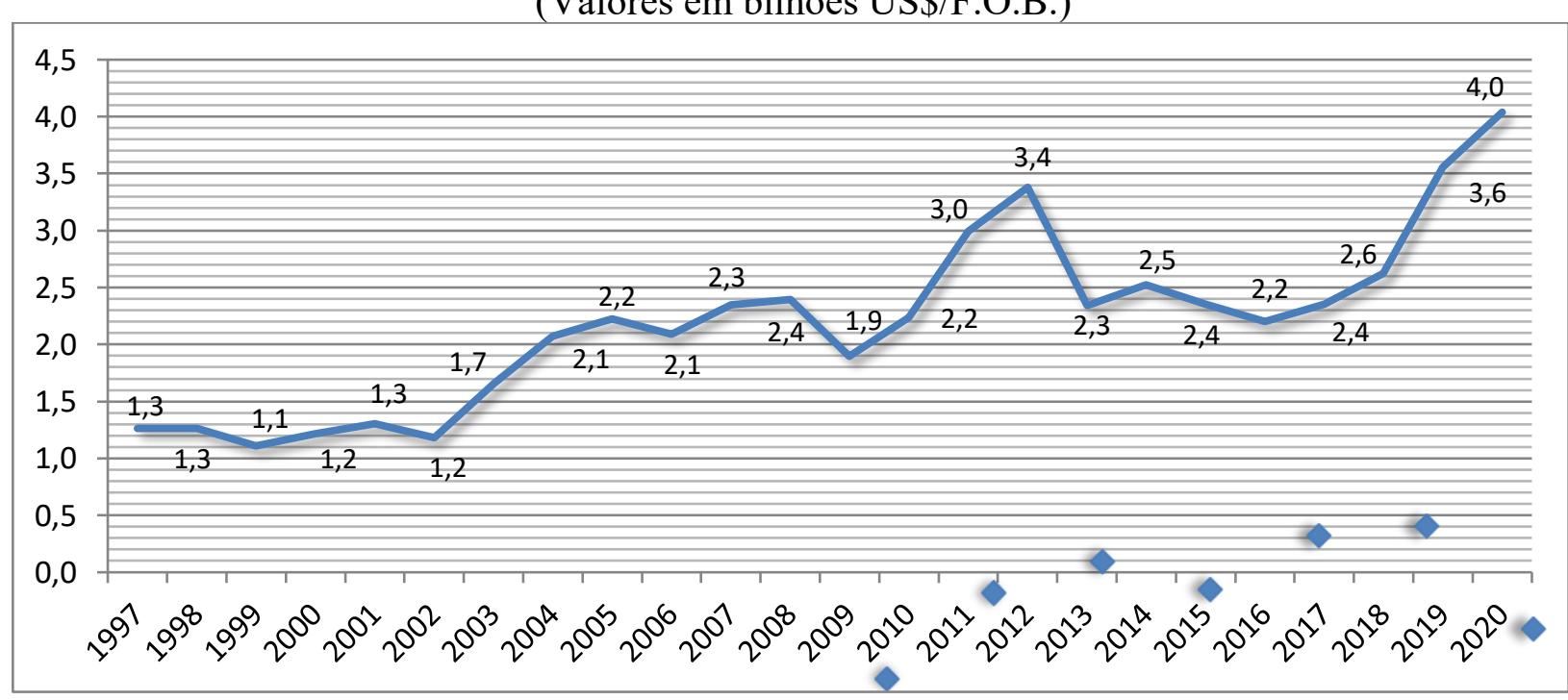

Fonte: Comex Stat, 2021a. Org. PEREIRA, L. A.G.; SANTOS, L. G. S., 2021.

$\mathrm{Na}$ evolução das exportações, observam-se as variações nos valores exportados, com destaque para o crescimento constante de 2000 a 2020, exceto no ano de 2002, 2006, 2009, 2013, 2015 e 2016. Essas variações foram explicadas pelos momentos de crises que diminuíram a demanda internacional, como exemplo, a crise de 2008; enquanto a concorrência de outros mercados exportadores afetou as exportações. Já o aumento nas exportações relaciona-se com o 
crescimento da demanda internacional, uma vez que é possível visualizar que 2012, 2019 e 2020, foram os anos que apresentaram os melhores desempenhos.

Ao considerar as exportações totais de produtos têxteis e de confecções no Brasil, no período de 1997 a 2020, observa-se que o algodão representou 42,01\% dos produtos exportados; os vestuários tiveram uma representação de 10,5\% nas exportações; os produtos denominados de outros tecidos participaram com 8,6\% das vendas para o exterior. Enquanto as exportações de tecidos de algodão representaram $8,3 \%$; os produtos roupas de cama e cortinas tiveram uma participação de 7,6\% dos valores exportados; os fios sintéticos representaram 3,2\% das exportações; os outros fios participaram com 2,3\%; os tecidos sintéticos participaram com 1,8\%; fios de algodão com $1,4 \%$; fibras sintéticas com $0,8 \%$ e os demais produtos somados representaram $13,5 \%$ das exportações de têxteis e confecções no Brasil, conforme mostra a tabela 1.

Tabela 1 - Exportações de produtos do setor têxtil no Brasil, acumulado no período de 1997-2020 (Valores em US\$/F.O.B. e percentuais)

\begin{tabular}{c|c|c}
\hline \multirow{2}{*}{ Descrição dos produtos exportados } & \multicolumn{2}{|c}{ Total } \\
\cline { 2 - 3 } & US\$ & \multicolumn{2}{|c}{ \% } \\
\hline Algodão & $21.961,7$ & \multicolumn{2}{|c}{8,6} \\
\hline Vestuários & $5.524,2$ & 8,3 \\
\hline Outros tecidos & $4.485,0$ & 7,6 \\
\hline Tecidos de algodão & $4.343,6$ & 3,2 \\
\hline Roupas de cama e cortinas & $3.979,0$ & 2,3 \\
\hline Fios sintéticos & $1.670,7$ & 1,8 \\
\hline Outros fios & $1.218,1$ & 1,4 \\
\hline Tecidos sintéticos & 962,0 & 0,8 \\
\hline Fios de algodão & 751,0 & 13,5 \\
\hline Fibras sintéticas & 400,7 & $\mathbf{2}$ \\
\hline Outros produtos têxteis & $7.072,7$ & $\mathbf{1 0 0 , 0}$ \\
\hline Total & $\mathbf{5 2 . 3 6 8 , 7}$ & \multicolumn{2}{|c}{} \\
\hline
\end{tabular}

Fonte: Comex Stat, 2021a. Org. PEREIRA, L. A.G.; SANTOS, L. G. S., 2021.

Ao analisar os produtos exportados, verifica-se que algodão foi o produto mais exportado, principalmente para o mercado asiático, por ser um produto básico na cadeia produtiva têxtil. $\mathrm{Na}$ evolução histórica das exportações de materiais têxteis e de confecções por mercados internacionais agrupados em continentes e/ou regiões, no período de 1997 a 2020, verifica-se uma expansão constante das exportações para os mercados asiáticos. A América do Sul foi o principal mercado de destino das exportações no início do período analisado; embora tenha ocorrido diminuição na sua participação nas exportações a partir de 2002, teve uma representação significativa como mercado comprador. A Europa teve uma participação em menor proporção que a Ásia e América do Sul, mas 
os valores exportados tiveram uma distribuição constante. A América do Norte participou significativamente nos primeiros anos do período analisado, mas reduziu as importações brasileiras de materiais têxteis e de confecções, conforme mostra o Gráfico 2.

Gráfico 2 - Brasil: exportações de matérias têxteis e de confecções por mercados internacionais, no período de 1997 a 2019 (Valorem 1.000.000 US\$/F.O.B. e Percentuais)

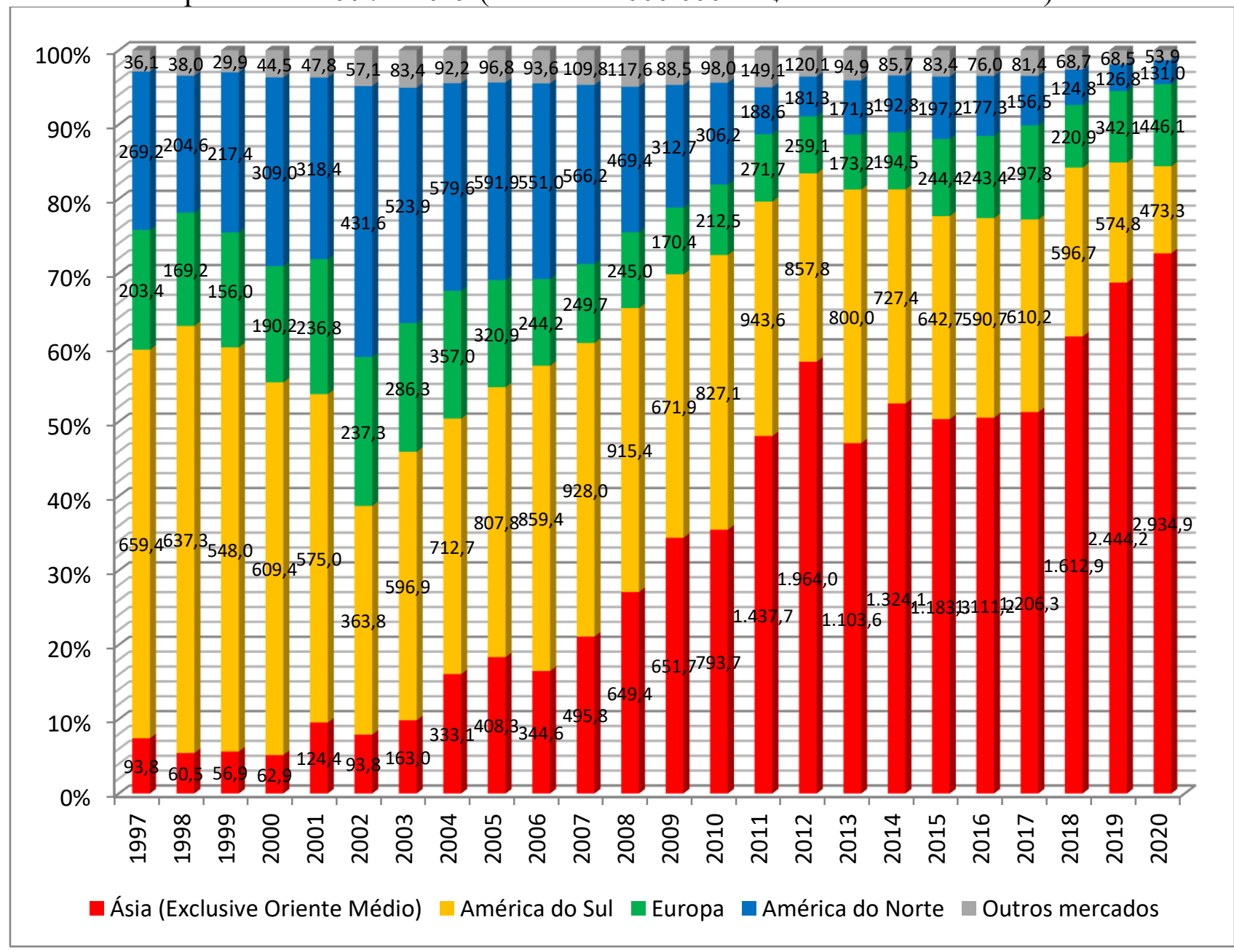

Fonte: Comex Stat, 2021a. Org. PEREIRA, L. A.G.; SANTOS, L. G. S., 2021.

Nos destinos das exportações de produtos têxteis, observa-se um aumento na participação do mercado asiático, devido à compra de produtos básicos (algodão sem caroço), e os mercados que compraram os produtos manufaturados reduziram as suas participações nas importações, como a América do Sul e América do Norte. Diante das variações na pauta de exportações de produtos têxteis e de confecções, as empresas brasileiras desse segmento conseguiram inserir seus produtos nos mercados internacionais, conforme já foi destacado. Assim, na seção seguinte, estudam-se as exportações de produtos têxteis e de confecções no norte do estado de Minas Gerais. 


\section{NORTE DE MINAS GERAIS: ORIGEM, EXPANSÃO E CONSOLIDAÇÃO DAS INDÚSTRIAS TÊXTEIS E DE CONFECÇÕES}

Para compreender o processo de expansão da indústria têxtil no norte de Minas Gerais e a sua inserção nos mercados internacionais, é preciso compreender, primeiramente, a organização desse setor no estado de Minas Gerais. A indústria têxtil vivenciou um processo de implantação e de expansão a partir do século XIX. Em 1872, a indústria têxtil se instalou de forma efetiva, à medida que se expandia um processo mais consolidado da estrutura produtiva industrial. Esse avanço da indústria têxtil ocorreu em função de duas mudanças estruturais: $1^{\text {a }}$ ) a implantação da tarifa Alves Branco, de 1844, que pôs fim à liberalização tarifária e favoreceu a indústria nacional; e $\left.2^{a}\right)$ a "extinção" do tráfico de escravos, em 1850, que passou a disponibilizar os capitais para realização de investimentos e mudou as relações de trabalho como forma de expandir o mercado consumidor. Essas medidas favoreceram a implantação da indústria têxtil no Brasil e consequentemente no estado de Minas Gerais (VAZ, 1977).

Em Minas Gerais, as indústrias têxteis passaram a se localizar territorialmente de forma estratégica nas proximidades das fontes de matérias-primas (algodão) e dos rios com cachoeiras para geração de energia empregada na estrutura produtiva. Além disso, o isolamento geográfico, caracterizado pelos gargalos na infraestrutura de transportes, favoreceu o crescimento da atividade industrial têxtil e impediu a concorrência de produtos têxteis produzidos em outros estados brasileiros (VAZ, 1977).

Para o Banco de Desenvolvimento de Minas Gerais - BDMG (1965), em 1865, foi implantada em Minas Gerais, por Bernardo Mascarenhas e irmão, a empresa têxtil Cedro e Cachoeira, que passou a atuar em escala industrial por meio do uso de equipamentos modernos na produção de tecidos. A partir de 1860, houve uma expansão da Cedro e Cachoeira no território mineiro, especialmente nas localidades de Santo Antônio do Machado, Pitangui, Sahara, Curvelo, Pará de Minas, Oliveira, Tamanduá e Dores do Indaiá. Posteriormente, unidades foram implantadas em Juiz de Fora, Bom Jesus da Água Fria (Itinga), Viçosa, Diamantina e Montes Claros. Segundo Moreira (2010), entre 1872 e 1889, foram instaladas, em Minas Gerais, vinte (20) unidades têxteis, sendo que as mais importantes se localizavam em Curvelo, Sete Lagoas e Santa Luzia e eram abastecidas pelo algodão produzido, principalmente, no norte de Minas Gerais. As demandas dos mercados consumidores favoreciam a consolidação da indústria têxtil, principalmente em localidades às margens das ferrovias; e, nas localidades em que não havia ferrovias, a indústria têxtil se instalou em centros de convergência populacional e comercial, como foi o caso de Montes Claros (BDMG, 1965). 
No expansionismo da indústria têxtil mineira, a lucratividade e o sucesso da Fábrica do Cedro e Cachoeira influenciaram e atraíram outros membros da família para o negócio, que, em 1877, inaugurou a Fábrica da Cachoeira em Curvelo (MG). As fábricas se fundiram em um cenário estratégico para impulsionar o desenvolvimento e deter a concorrência de empresas têxteis que surgiam em Minas Gerais (MASCARENHAS, 1972). O contexto de expansão da produção, de processamento e de comercialização de algodão contribuiu para a implantação da indústria têxtil em municípios localizados na porção norte de Minas Gerais, especialmente em Montes Claros e Pirapora.

O surgimento da indústria têxtil em Montes Claros ocorreu no século XIX. Segundo Paula (2007), em 1882, inicia-se a atividade da fábrica de tecidos, localizada a cerca de uma légua da cidade de Montes Claros, a qual usava as máquinas que chegaram em carro de boi e lombo de burro. Para Oliveira (2000), a Fábrica de Tecidos Montes Claros foi a primeira indústria a se instalar na referida cidade que, por dificuldades financeiras, foi comprada pela Companhia Cedro Cachoeira; consequentemente, foram transferidos os equipamentos para a Fábrica de Tecidos Santa Helena, criada em 1914 (PAULA, 2007). Segundo Paula (2007), em 1950, a atividade industrial em Montes Claros estava concentrada em indústrias ligadas ao processamento de algodão e fabricação de tecidos, as quais eram: Fábrica de Tecidos Santa Helena, Sociedade Algodoeira Montes Clarense Ltda., Usina de Beneficiamento de Algodão e Indústrias Reunidas Santa Maria. Em Montes Claros, a Fábrica Fiação e Tecidos Santa Helena tinha 72 teares e 2.820 fusos, empregando 156 pessoas (CETEX, 1946).

Segundo Silva, Diniz e Mota (2000), a partir de 1902, a Companhia Cedro e Cachoeira construiu em Pirapora um depósito para distribuição de tecidos que eram comercializados e transportados em vapores para mercados ao longo da hidrovia do São Francisco. No retorno, os vapores traziam algodão para abastecer as fábricas de tecidos. No contexto do dinamismo econômico, industrial e comercial da atividade algodoeira e têxtil, a implantação da infraestrutura ferroviária em Pirapora (1910) e Montes Claros (1926) foi importante para integração com outros centros urbanos de Minas Gerais e do Brasil (PEREIRA; LESSA, 2012). Além da ferrovia, Pereira (2010) destacou que, em Pirapora, o transporte hidroviário teve a participação importante na atividade industrial e comercial naquele período.

Até por volta do início da década de 1960, a atividade industrial tinha baixa participação na dinâmica econômica. Isso mudou com a inclusão de municípios do norte de Minas Gerais na área de atuação da Superintendência do Desenvolvimento do Nordeste (SUDENE), que juntamente com outros órgãos estatais, como Banco do Nordeste do Brasil (BNB), Banco de Desenvolvimento de Minas Gerais (BDMG), entre outros, passaram a incentivar por meio de financiamentos e de 
isenções fiscais a expansão da atividade industrial. Para esse feito, houve investimento e melhoria na infraestrutura de transporte, energia e telecomunicações (OLIVEIRA, 2000; PEREIRA, 2010). Na perspectiva da industrialização em Montes Claros e Pirapora, destaca-se a criação dos distritos industriais nas duas cidades.

Para Braga (2008), o impulso de atividades produtivas na região norte-mineira teve relação com a implantação do parque industrial, que impulsionou a instalação de novas indústrias por meio das políticas de incentivos fiscais executadas pela SUDENE e que, como resultado, modificou as estruturas produtivas. Dessa forma, a indústria têxtil reestrutura-se e novas plantas surgem em Montes Claros e Pirapora como forma de aproveitamento de matéria-prima (algodão), dos incentivos e das demandas dos mercados consumidores.

No processo de expansão da indústria têxtil, no período posterior à atuação da SUDENE no norte de Minas Gerais, Montes Claros se destacou pela criação da Companhia de Tecidos Norte de Minas (COTEMINAS), em 1967, cujas operações foram iniciadas em 1975 com a fabricação de fios e tecidos. Nas décadas de 1980 e 1990, a Coteminas expandiu as suas unidades no Nordeste (Rio Grande do Norte e Paraíba), assim, adquiriu e construiu novas fábricas, bem como atuou na compra de algumas empresas do segmento têxtil (Santista e Artex). Em 2004, a Coteminas tornouse uma acionista relevante da Companhia de Tecidos Santanense, que tem unidade em Montes Claros. Na atuação internacional, em 2005, foi criada a Springs Global, a partir da associação entre a Coteminas e Springs Industries dos Estados Unidos, que concentraram as suas atividades em artigos de cama e banho (COTEMINAS, 2021).

Em 1976, o Grupo Santanense passou a atuar em Montes Claros, ao adquirir a unidade da empresa Fiação Têxtil Santa Helena. Em 2004, esse grupo passou a fazer parte da Coteminas, como forma de se tornar mais competitiva no mercado, assim, aproveitou a experiência no design e na prestação de serviços em escala global. O grupo Coteminas cresceu e passou a ter uma estrutura construída de 15 fábricas no Brasil, cinco fábricas nos Estados Unidos, uma fábrica na Argentina e uma fábrica no México (SANTANENSE, 2021).

Na cidade de Pirapora, em 1984, instala-se a unidade da Companhia Fiação e Tecidos Cedronorte. Em 1996, a Companhia Fiação e Tecidos Santo Antônio - Grupo Cedro e Cachoeira instala uma unidade produtiva em território piraporense (SILVA; DINIZ; MOTA, 2000). As unidades produtivas das empresas do Grupo Cedro Têxtil se localizam em Pirapora, Sete Lagoas e Caetanópolis. Além dessas, há a sede administrativa em Belo Horizonte e o centro de distribuição em Contagem (CEDRO TÊXTIL, 2021).

Os grupos Coteminas e Cedro Têxtil são as duas principais corporações do setor têxtil localizadas no norte de Minas Gerais que produzem e exportam tecidos e produtos de cama e 
banho. Além desses grupos empresariais, um grupo de empresas do setor de têxtil e de confecções, também localizadas na região norte-mineira, inseriu os seus produtos nos mercados internacionais, destacando-se a Amil Confecções (Espinosa), a Protej Equipamentos de Segurança (Taiobeiras), a Latitud Cero (Salinas), a M. C. Comércio (Pirapora), a Têxtil Paculdino (Montes Claros), Soperer Comércio e Comercial Raufonso (Januária), Arte Manhas (Janaúba) e a Taty Modas (Montes Claros). Essas informações são mostradas no Mapa 2.

Mapa 2 - Norte de Minas Gerais: infraestrutura de transportes e localização das empresas exportadoras de produtos têxteis e confecções

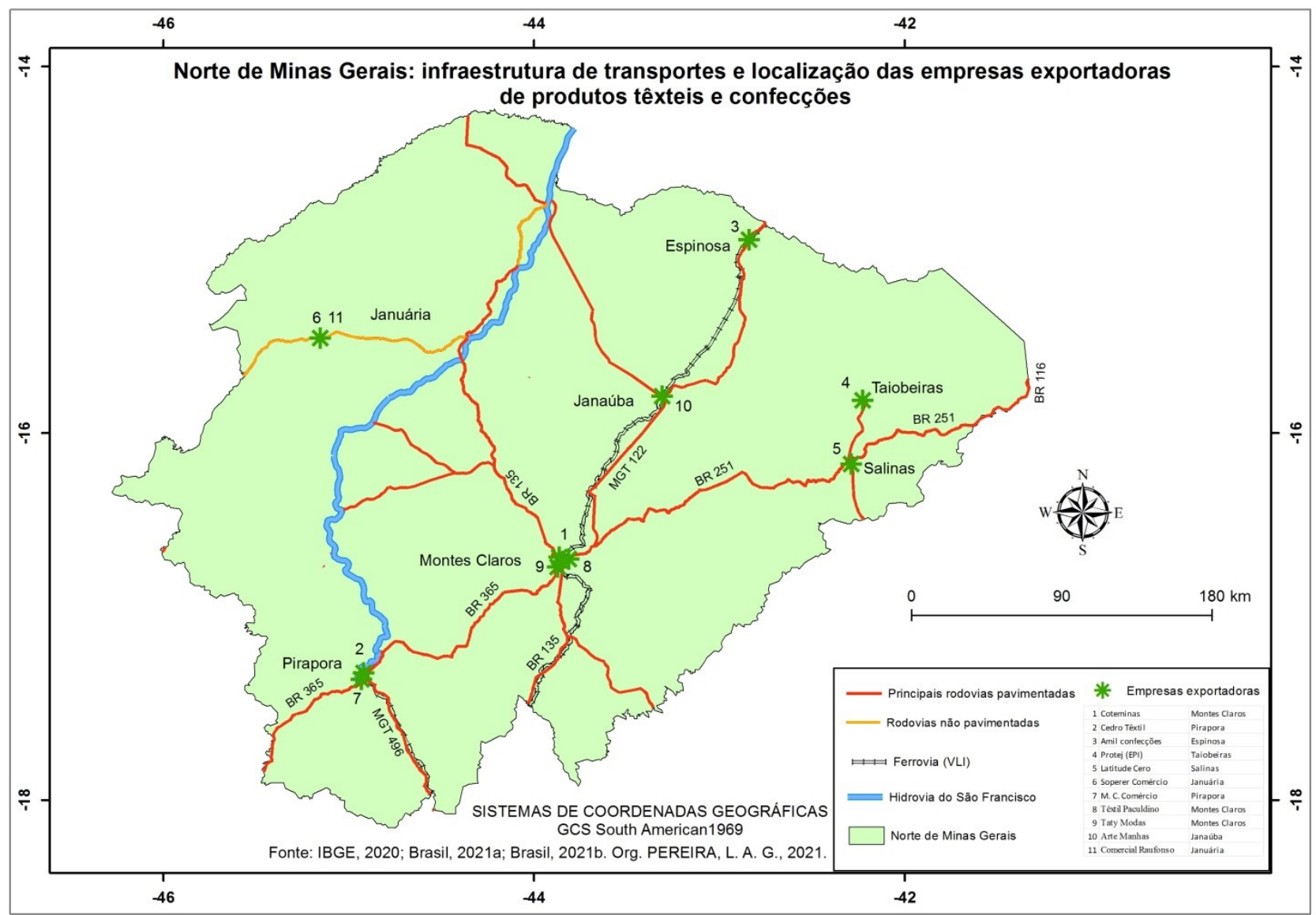

Fonte: IBGE, 2020; Brasil, 2021a; Brasil, 2021b. Org. PEREIRA, L. A. G., 2021.

Considerando a localização geográfica das empresas exportadoras de produtos têxteis e confecções no norte de Minas Gerais, observa-se que elas estruturaram as suas redes de suprimentos e de distribuição por meio da infraestrutura e de serviços de transporte rodoviário e ferroviário. A maioria delas recebe os incentivos governamentais brasileiros previstos em legislações vigentes em políticas públicas de desenvolvimento regional. Além disso, os grandes grupos empresariais desse segmento possuem maquinarias modernas com elevada capacidade produtiva de produtos de qualidade para a exportação, que será abordado na sequência. 


\section{A GEOGRAFIA DAS EXPORTAÇÕES NO NORTE DE MINAS GERAIS E A INSERÇÃO DE PRODUTOS DAS INDÚSTRIAS TÊXTEIS E DE CONFECÇÕES NOS MERCADOS GLOBAIS}

Em um cenário econômico internacional de muita competitividade, as indústrias têxteis e de confecções localizadas nos municípios do norte de Minas Gerais são capazes de inserir seus produtos nos mercados globais, mas enfrentam a concorrência de empresas do segmento de outros países, sobretudo as empresas chinesas. $\mathrm{Na}$ evolução histórica das exportações somadas das indústrias têxteis e de confecções na região norte-mineira, os indicadores mostraram um comportamento de oscilações do setor no período entre 1997 e 2020, destacando-se que, em 1997 e 1998, a indústria têxtil e a de confecções tinham pouca participação nas exportações. No período de 1999 a 2007, ocorreu uma elevação significativa nos valores das exportações de produtos têxteis e de confecções, enquanto nos anos de 2008 a 2011, verifica-se uma queda significativa nas exportações; voltando a crescer um pouco, de 2012 a 2015, e, a partir de 2016, as exportações apresentaram queda, conforme mostra o Gráfico 3.

Gráfico 3 - Evolução das exportações da indústria têxtil em Montes Claros e Pirapora, no período de 1997 a 2020 (valores em 1.000.000 US\$/F.O.B. - moeda corrente)

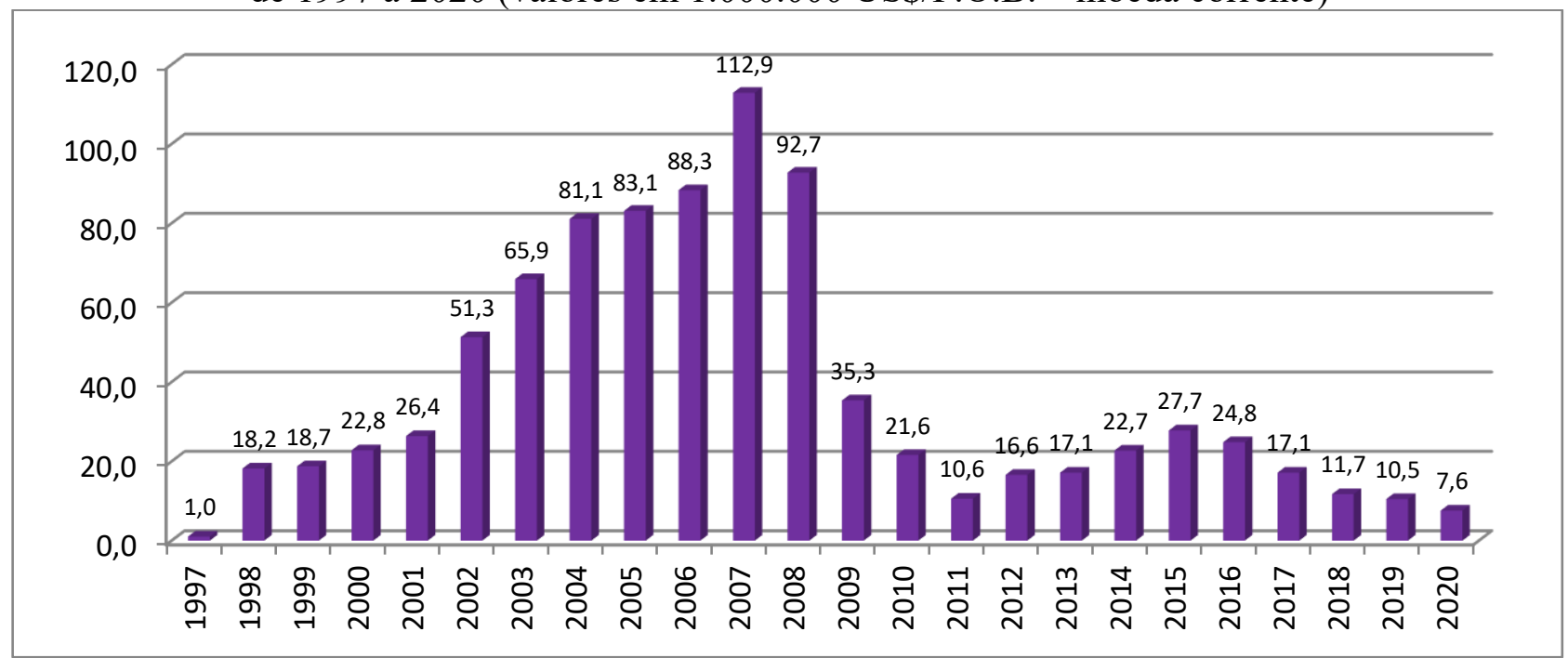

Fonte: Comex Stat, 2021b. Org. PEREIRA, L. A.G.; SANTOS, L. G. S., 2021. Nota: Em Pirapora não teve exportação de produtos têxteis nos anos de 1997, 1998, 2018 e 2019.

No norte de Minas Gerais, é perceptível a expansão significativa das exportações de produtos têxteis e de confecções no período de 1997 a 2007, destacando-se o ano de 2007, por ter registrado o melhor desempenho em razão da expansão das exportações direcionadas aos mercados dos Estados Unidos da América e da Argentina. Depois de 2008, verificou-se uma queda constante nas exportações, mesmo no período que apresentou leve crescimento (2011 a 2015); os valores sequer superam os indicadores no período anterior a 2002. Essa queda nas exportações no norte de 
Minas Gerais está relacionada com o fim do Acordo Multifibras (Acordo sobre Têxteis e Vestuário) que acentuou a competividade de empresas asiáticas nos mercados internacionais.

$\mathrm{Na}$ análise das exportações de produtos têxteis e de confecções por municípios, no período analisado, verifica-se uma concentração significativa nos municípios de Montes Claros e Pirapora no período de 1999 a 2016, tendo melhor desempenho em 2001 e 2011 nas exportações de produtos têxteis e de confecções. Já os demais municípios tiveram pouca participação nas exportações no período analisado, exceto em 1997, em que tiveram uma participação de quase metade das exportações, conforme mostra o Gráfico 4.

Gráfico 4 - Norte de Minas Gerais: evolução das exportações da indústria têxtil por municípios, no período de 1997 a 2020 (valores em 1.000.000 US\$/F.O.B.)

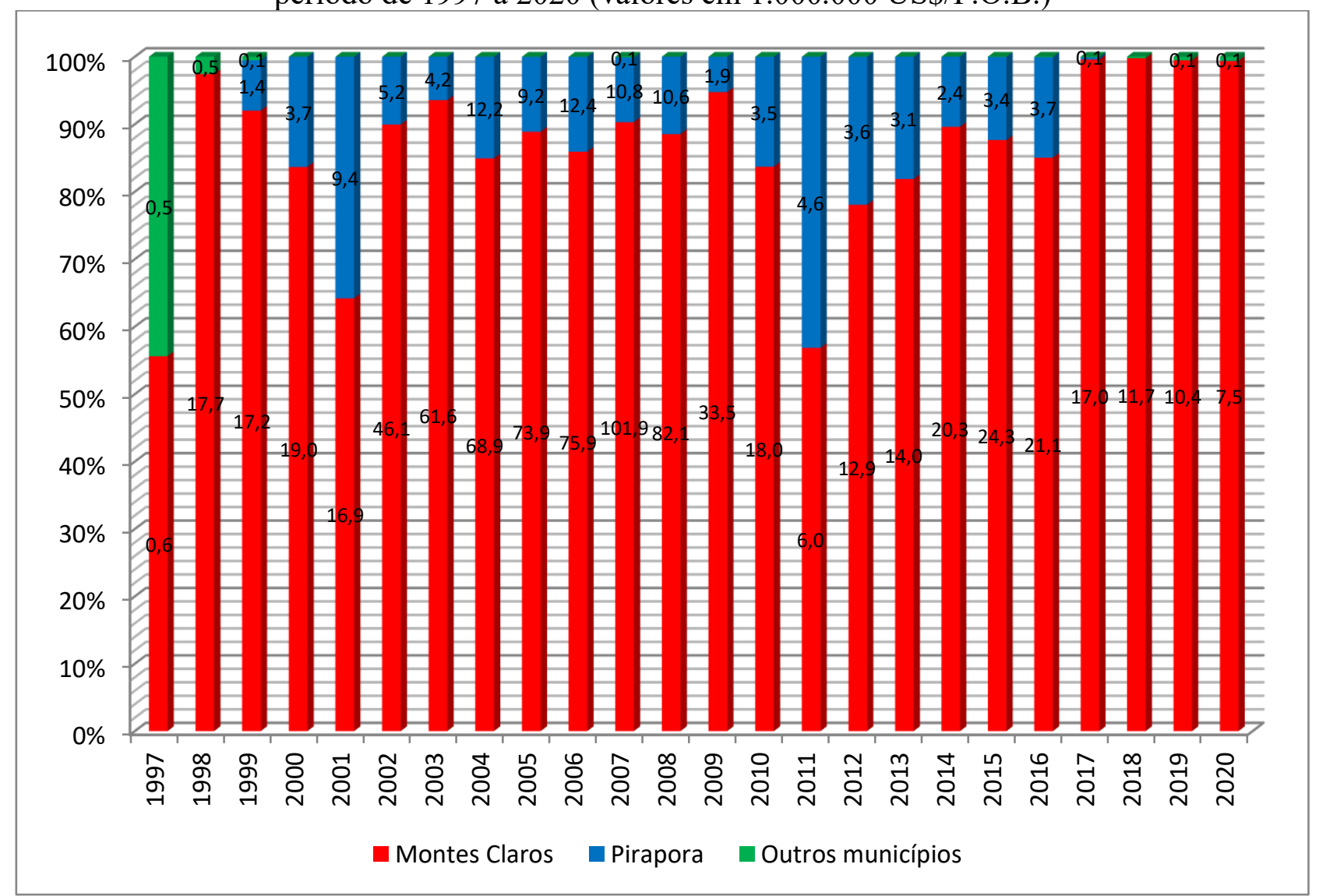

Fonte: Comex Stat, 2021b. Org. PEREIRA, L. A.G.; SANTOS, L. G. S., 2021. Nota: Em Pirapora não teve exportação de produtos têxteis nos anos de 1997, 1998, 2018 e 2019.

Observa-se no período analisado que os produtos roupas de cama tiveram uma participação de $60,18 \%$ dos valores exportados; os produtos tecidos de algodão representaram 30,26\% das exportações; os tecidos de fibras sintéticas obtiveram $7,12 \%$ das exportações em valores financeiros; o algodão representou 2,02\% dos produtos exportados; as sacarias participaram das exportações com $0,30 \%$; os vestuários tiveram uma representação de $0,04 \%$ nas exportações e os 
demais produtos somados tiveram uma participação de $0,08 \%$ nas exportações de produtos têxteis e de confecções, conforme a Tabela 1.

Tabela 1 - Exportações de produtos do setor têxtil em Montes Claros e Pirapora, acumulado no período de 1997-2020 (Valores em US\$/F.O.B. e percentuais)

\begin{tabular}{|c|c|c|c|c|c|}
\hline Cidades/Região & Montes Claros & Pirapora & Outros & \multicolumn{2}{|l|}{ Total } \\
\hline Descrição SH4 & US\$ & US\$ & US\$ & US\$ & $\%$ \\
\hline Roupas de cama & 532.933 .534 & - & - & 532.933 .534 & 60,18 \\
\hline Tecidos de algodão & 161.682 .250 & 105.366 .481 & 868.624 & 267.917 .355 & 30,26 \\
\hline $\begin{array}{c}\text { Tecidos de fibras } \\
\text { sintéticas }\end{array}$ & 62.826 .856 & 29.651 & 148.641 & 63.005 .148 & 7,12 \\
\hline Algodão & 17.847 .319 & 67 & - & 17.847 .386 & 2,02 \\
\hline Sacarias & 2.660 .082 & - & 1.331 & 2.661 .413 & 0,30 \\
\hline Vestuários & 57.779 & 47.589 & 292.017 & 397.385 & 0,04 \\
\hline Outros produtos têxteis & 718.302 & 9.895 & 7.280 & 735.477 & 0,08 \\
\hline Total & 778.726.122 & 105.453 .683 & 1317893 & 885.497 .698 & 100,00 \\
\hline Participação percentual & 87,94 & 11,91 & 0,15 & 100,00 & - \\
\hline
\end{tabular}

Fonte: Comex Stat, 2021b. Org. PEREIRA, L. A.G.; SANTOS, L. G. S., 2021. Nota: Nesta tabela, a categoria outros representa os municípios de Espinosa, Taiobeiras, Januária, Janaúba, Várzea da Palma e Salinas.

Os dados mostram que as exportações de produtos têxteis e de confecções concentraram no município de Montes Claros, que teve uma participação de 87,94\%; seguido por Pirapora, que representou $11,91 \%$, e os demais municípios tiveram uma representação de apenas $0,15 \%$. Isso mostra uma concentração dos exportadores principalmente nos municípios de Montes Claros e de Pirapora. Considerando as exportações dos produtos por destinos internacionais, observa-se uma concentração nos mercados da América do Sul, no período de 1997 a 2001 e de 2011 a 2019. E, no período de 2002 a 2010, as exportações foram concentradas nos mercados da América do Norte. No caso da Europa, a participação mais expressiva ocorreu nos anos de 2000 e 2001. Para os demais mercados a inserção das exportações foi pouco representativa, conforme mostra o Gráfico 5.

Por meio da representação das exportações de produtos têxteis e de confecções por mercados internacionais identificados por países/territórios, nota-se que 52,8\% dos produtos exportados foram direcionados aos Estados Unidos; 29,7\% das exportações seguiram para o mercado argentino; o mercado mexicano recebeu 9,2\% dos produtos exportados; os mercados do Chile, Uruguai e Venezuela receberam as exportações em uma faixa de valor que representou entre $1,2 \%$ e 1,3\%; os demais países compraram valores financeiros inferiores a 0,9\%. Essas informações podem ser observadas no Mapa 3. 
Gráfico 5 - Norte de Minas Gerais: exportações de produtos têxteis e confecções por mercados internacionais (valores em 1.000.000 US\$/F.O.B. e Percentuais)

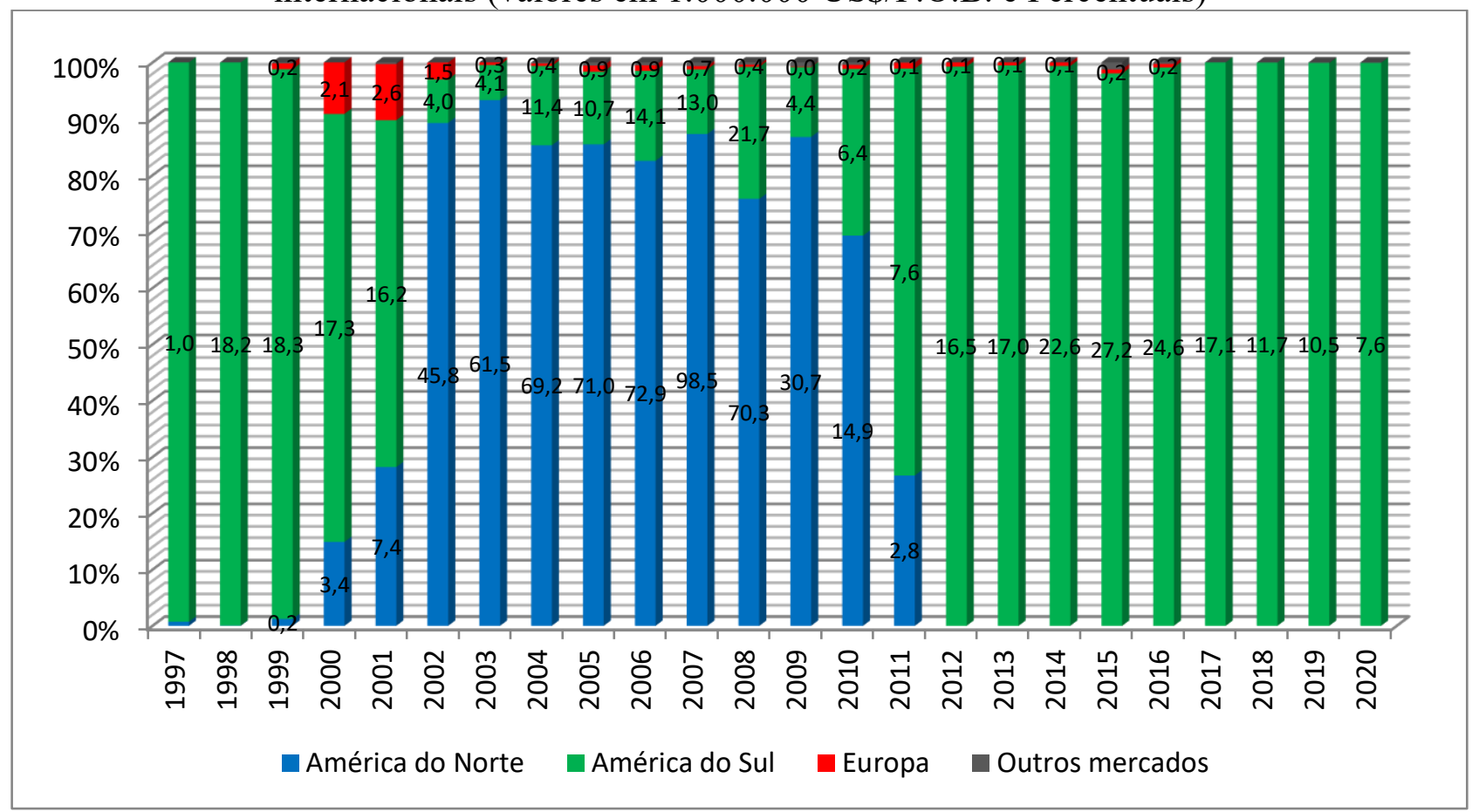

Fonte: Comex Stat, 2021b. Org. PEREIRA, L. A.G.; SANTOS, L. G. S., 2021.

Mapa 3 - Norte de Minas Gerais: exportações de produtos têxteis e de confecções por mercados internacionais, acumulado no período de 1997 a 2020 (Valores em US\$/F.O.B. e Percentuais)

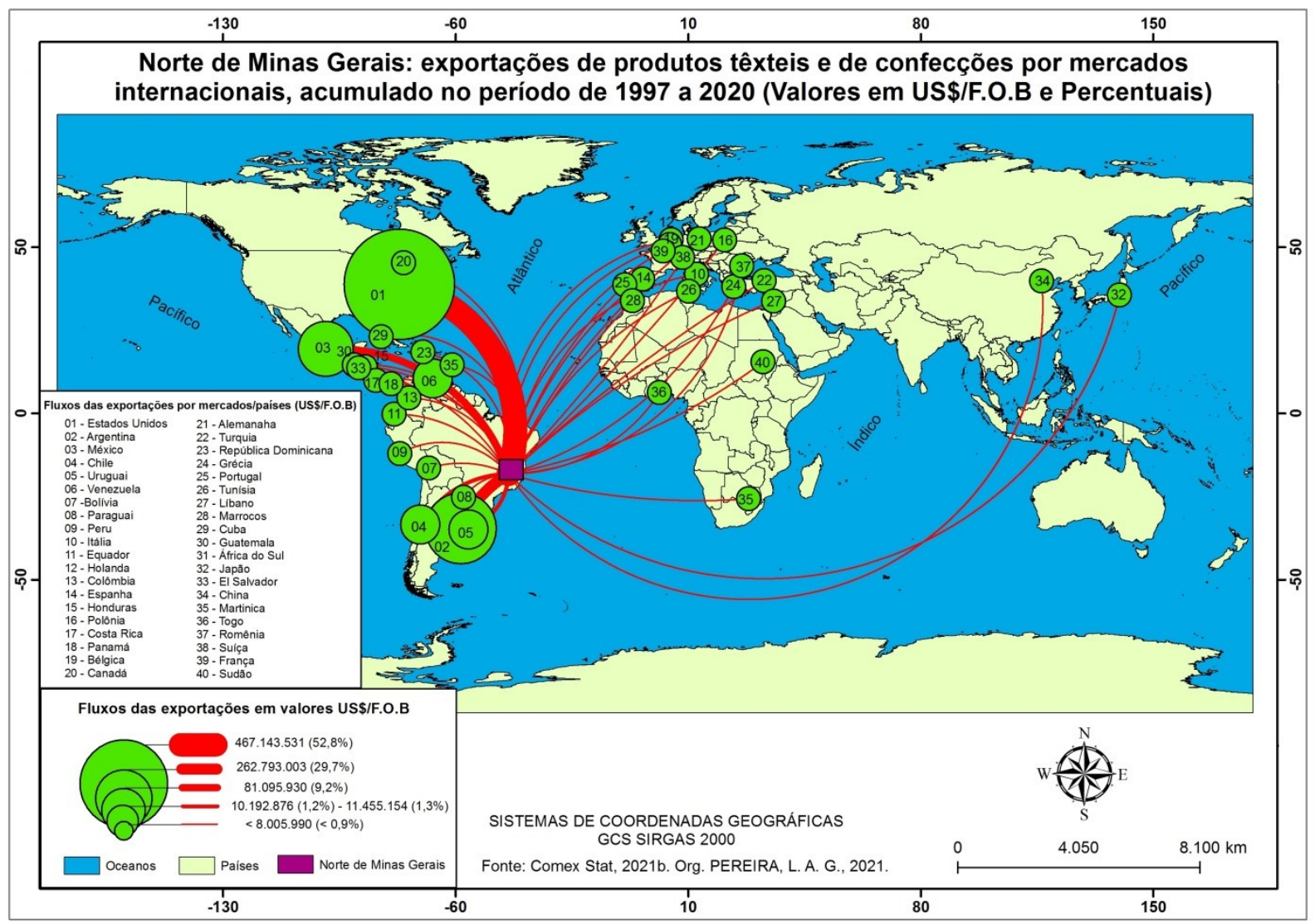

Fonte: Comex Stat, 2021b. Org. PEREIRA, L. A. G., 2021. 
As exportações de produtos têxteis e de confecções no norte de Minas Gerais estão concentradas, principalmente, nos municípios de Montes Claros e Pirapora. Os produtos exportados foram roupas de cama, tecidos de algodão, tecidos de fibras sintéticas, entre outros produtos. Os produtos exportados atenderam as demandas de mercados compradores da América do Norte (Estados Unidos e México) e da América do Sul (Argentina, Chile, Uruguai e Venezuela).

\section{CONSIDERAÇÕES FINAIS}

O dinamismo da indústria têxtil e de confecções mundial é caracterizado pela sua importância na estrutura de setores da economia no comércio global, uma vez que esse segmento vivenciou as transformações na organização produtiva e comercial, principalmente a partir da década de 1970. A consolidação da estrutura de produção e de consumo flexível provocou mudanças no setor têxtil e de confecções por meio da deslocalização dos processos produtivos dos países desenvolvidos para países em desenvolvimento, buscando a redução dos custos operacionais em linhas de produção e a garantia de competitividade de seus produtos. Isso reorganizou a atividade industrial no espaço geográfico mundial e aumentou a terceirização de serviços e de linhas de produção, à medida que ampliou o comércio intraempresa e interempresa. Nesse processo, as empresas localizadas na China passaram a concentrar 30\% das exportações de produtos têxteis e de confecções nos mercados internacionais.

As exportações brasileiras de produtos do setor têxtil e de confecções concentraram produtos direcionados à cadeia de insumos, principalmente no algodão, que teve um crescimento contínuo na comercialização internacional. Diferentemente do Brasil, no norte de Minas Gerais, as exportações do setor em estudo concentram em roupas de cama, tecidos de algodão e tecidos de materiais sintéticos. No cenário de competividade de produtos têxteis e de confecções, na região norte-mineira, duas corporações (Grupo Coteminas e Grupo Cedro Têxtil) conseguiram sobressair e inserir os seus produtos nos mercados internacionais, entretanto, outras corporações, em proporção bem menor, também conseguiram exportar seus produtos.

$\mathrm{Na}$ evolução das exportações de têxteis e de confecções na região norte-mineira, percebe-se que no período de 1997 a 1999 as exportações foram incipientes. No período de 2000 a 2007, houve um crescimento sucessivo e significativo nas exportações do setor em estudo, sendo que, em 2007, as exportações apresentaram o melhor desempenho. Depois de 2009, nota-se um momento de queda brusca nas exportações, devido à crise econômica global (2008) e ao fim do Acordo Multifibras (Acordo sobre Têxteis e Vestuário), que dificultaram as atuações de empresas brasileiras e nortemineiras de se posicionarem de maneira mais competitiva no mercado internacional. No período de 
2012 a 2015, as exportações voltaram a ter um pequeno crescimento, entretanto, novamente, decresceram no período de 2016 a 2020.

Considerando os fluxos de exportações, o estudo mostrou um cenário de muitas oscilações e os dados acumulados em todo período (1997 a 2020) mostram que os agentes econômicos nos Estados Unidos, Argentina e México foram os que mais importaram produtos do setor têxtil e de confecções, representando juntos $91,6 \%$ dos valores das compras. Depois de 2005, com o fim do Acordo sobre Têxteis e Vestuário (ATV), favoreceu-se a liberalização e a expansão dos mercados globais para as empresas do setor têxtil e de confecções localizadas na Ásia, principalmente na China, que passaram a competir também nos mercados atendidos por empresas localizadas na região norte-mineira, o que criou dificuldade no setor de têxtil e de confecções do Brasil e do Norte de Minas - que produz bens manufaturados - para inserir os seus produtos nos mercados internacionais.

Nesse cenário de concorrência acirrada no comércio global, a sobrevivência do setor têxtil e de confecções no norte de Minas Gerais é de fundamental importância para a economia industrial e para a cadeia produtiva local-regional, demandando investimentos em inovações tecnológicas e em modernização das unidades de produção para reduzir custos operacionais, ampliar e assegurar a inserção de seus produtos nos mercados globais.

\section{AGRADECIMENTOS}

À Fundação de Amparo à Pesquisa de Minas Gerais pelo financiamento do projeto pesquisa ao qual está vinculado este estudo.

\section{REFERÊNCIAS}

ALBUQUERQUE, R. H. L. P. Capital comercial, indústria têxtil e produção agrícola. São Paulo: Hucitec, 1982.

ARRUDA, J. J. A. O algodão brasileiro na época da revolução industrial. América Latina en la Historia Económica, México, v. 23, n. 2, p. 167-203, agosto 2016. Disponível em: http://www. scielo.org.mx/scielo.php?script=sci arttext\&pid=S1405-22532016000200167\&lng=es\&nrm=iso.

Acesso em: jun. 2020.

BANCO DE DESENVOLVIMENTO DE MINAS GERAIS - BDMG. A indústria têxtil em Minas Gerais: Condições e Reequipamento. Belo Horizonte: BDMG, 1965.

BORÇA JUNIOR, G. R.; TORRES FILHO, E. T. Analisando a Crise do Subprime. Revista do BNDES, Rio de Janeiro, v. 15, n. 30, p. 129-159, 2008. 
BRAGA, M. A. F. Industrialização da Área Mineira da SUDENE: um estudo de caso - Montes Claros. Montes Claros: Unimontes, 2008.

BRASIL. Ministério da Economia. Lista de empresas exportadoras e importadoras. 2021a. Disponível em: https://www.gov.br/produtividade-e-comercio-exterior/pt-br/assuntos/comercioexterior/estatisticas/empresas-brasileiras-exportadoras-e-importadoras. Acesso em: 25 nov. 2021.

BRASIL. Ministério da infraestrutura. Mapas e bases dos modos de transportes. $2021 \mathrm{~b}$. Disponível em: https:/www.gov.br/infraestrutura/pt-br/assuntos/dados-de-transportes/bit/bitmodos mapas. Acesso em: 25 nov. 2021.

CAMPOS, A. C.; PAULA, N. M. A indústria têxtil brasileira em um contexto de transformações mundiais. Revista Econômica do Nordeste [on-line], Fortaleza, v. 37, n. 4, p. 592-608, 2006. Disponível em: https://ren.emnuvens.com.br/ren/article/view/666. Acesso em: $10 \mathrm{dez} 2020$.

CEDRO TÊXTIL. Institucional - História. 2021. Disponível em: https://www.cedro.com.br/ Institucional/Institucional. Acesso em: jan. 2021.

CLEMENTINO, M. L. M. A evolução da indústria têxtil no contexto da afirmação do imperialismo americano. Colóquio Internacional de Geocrítica, 12., 2012, Bogotá. Anais ... Bogotá: Geocrítica, 2012. p. 1-13. Disponível em: http://www.ub.edu/geocrit/coloquio2012/actas/01-M-Miranda.pdf. Acesso em: 05 de fev. 2020.

COMEX STAT. Exportação e Importação Geral. Brasília; Comex Stat, 2021a. Disponível em:

COMEX STAT. Exportação e Importação Municípios. Brasília; Comex Stat, 2021b. Disponível em: http://comexstat.mdic.gov.br/pt/municipio. Acesso em: 10 jul. 2021.

COMISSÃO EXECUTIVA TÊXTIL - CETEX. Indústria têxtil algodoeira. Rio de Janeiro: Ministério do Trabalho Indústria e Comércio, 1946.

COMPANHIA DE TECIDOS NORTE DE MINAS - COTEMINAS. A companhia - História. 2021. Disponível em: http://www.ctnm.com.br/a-companhia/historia/. Acesso em: 10 fev. 2021.

COSTA, A. C. R.; ROCHA, E. R. P. Panorama da cadeia produtiva têxtil e de confecções e a questão da inovação. BNDES Setorial, Rio de Janeiro, n. 29, p. 159-202, mar. 2009.

CUNHA, G. H. M. Ensaios sobre a economia da província do Ceará durante do século XIX. Revista Economia Política Do Desenvolvimento, Maceió, v. 5, n.7, p. 98-111, 2018.

Datos comerciales mensuales, trimestrales y anuales. Valores de importación y exportación, volumenes, tasas de crecimiento, cuotas de mercado, etc. 2021. Disponível em: https://www. trademap.org/Index.aspx?nvpm $=3 \% 7 \mathrm{c} \% 7 \mathrm{c} \% 7 \mathrm{c} \% 7 \mathrm{c} \% 7 \mathrm{c} \% 7 \mathrm{c} \% 7 \mathrm{c} \% 7 \mathrm{c} \% 7 \mathrm{c} \% 7 \mathrm{c} \% 7 \mathrm{c} \% 7 \mathrm{c} \% 7 \mathrm{c} \% 7 \mathrm{c} \% 7$ c\%7c\%7c. Acesso em: 10 jul. 2021.

FILLETI, J. P.; BOLDRIN, R. A indústria têxtil no Brasil: um modelo econométrico analisando a hipótese de desindustrialização setorial. Economia e Sociedade, Campinas, v. 29, n. 3, p. 861-890, 2020. Disponível em: https://www.scielo.br/j/ecos/a/mVnzhNqypchK4xnrqXnJ3QC/. Acesso em: 01 maio 2021.

FRAGA, A. Da rotina à flexibilidade: análise das características do Fordismo fora da indústria. Revista habitus, Rio de Janeiro, v.3, n. 1, p. 36-43, 2006. Disponível em: https://revistas .ufrj.br/index.php/habitus/article/view/11266. Acesso em: 10 maio 2021. 
FUJITA, R. M. L; JORENTE, M. J. A Indústria Têxtil no Brasil: uma perspectiva histórica e cultural. Revista Moda Palavra e-periódico, Florianópolis, v.8, n.15, p. 153-174, 2015. Disponível em: https://www.revistas.udesc.br/index.php/modapalavra/article/view/5893. Acesso em: 10 maio 2021.

GORINI, A. P. F. Panorama do setor têxtil no Brasil e no mundo: reestruturação e perspectiva. BNDS Setorial, Rio de Janeiro, n. 12, p. 17-50, set. 2000.

HOBSBAWM, E. J. A era das revoluções: 1789-1848. São Paulo: Paz e Terra, 2010.

INSTITUTO BRASILEIRO DE GEOGRAFIA E ESTATÍSTICA - IBGE. Cartas e mapas. 2020. Disponível em: https://www.ibge.gov.br/geociencias. Acesso em: 10 set. 2020.

KON, A.; COAN, D. C. Transformações da indústria têxtil brasileira: a transição para a modernização. Revista de Economia Mackenzie, São Paulo, v. 3, n. 3, p. 11-34, 2005.

LAL, Kaushalesh. The Textiles and Clothing Industry and Economic Development: A Global Perspective. In: LAL, Kaushalesh; MOHNEN, Pierre A. Innovation Policies and International Trade Rules: The Textiles and Clothing Industry in Developing Countries. New York: Palgrave Macmillan, 2009.

LIMA, E. C.; OLIVEIRA NETO, C. R. Revolução Industrial: considerações sobre o pioneirismo industrial inglês. Revista Espaço acadêmico, [S./1.], v. 17, n. 194, p. 102-113, 2017. Disponível em: http://periodicos.uem.br/ojs/index.php/EspacoAcademico/article/view/32912 Acesso em: 20 mar. 2020.

LIMA, R. J. C. O Fim do Acordo Multifibras e o Comércio Brasil-China em Têxteis e Vestuário Uma análise segundo o Índice de Vantagens Comparativas Reveladas. Revista Brasileira de Comércio Exterior, [S./1.], v. 98, p. 40-51, 2009.

LISBOA, S. A. A. A organização da indústria têxtil brasileira no contexto internacional. 2013. 33f. Monografia (Graduação em Economia), Pontifícia Universidade Católica do Rio de Janeiro, Departamento de Economia, Rio de Janeiro, 2013.

MASCAREnHAS, G. M. Centenário da fábrica do Cedro: 1872-1972. Belo Horizonte: Cia. de Fiação e Tecidos Cedro e Cachoeira S.A, 1972.

MASSUDA, E. M. Transformações recentes da indústria têxtil brasileira (1992-1999). Acta Scientiarum, Maringá, v. 24, n. 1, p. 243-251, 2002. Disponível em: http://eduem.uem. br/ojs/index.php/ActaSciHumanSocSci/article/viewFile/2443/1710. Acesso em: 10 mai. 2021.

MENDES JUNIOR, B. O. A indústria têxtil no Nordeste, Norte de Minas e norte do Espírito Santo - contextualização e perspectivas. Cadernos Setorial ETENE, Fortaleza, v. 4, n. 101, 1-17, 2019.

MOREIRA, H. F. "Se for para morrer de fome, eu prefiro morrer de tiro": O Norte de Minas e a formação de lideranças rurais. 2010. 139f. Dissertação (Mestre em Ciências Sociais) - Programa de Pós-Graduação em Ciências Sociais em Desenvolvimento, Agricultura e Sociedade, UFFRRJ, 2010.

OLIVEIRA, M. F. M. O processo de desenvolvimento de Montes Claros e da Área Mineira da SUDENE. In: OLIVEIRA, M. F. M.; RODRIGUES, L. (Org.). Formação Social e Econômica do Norte de Minas. Montes Claros: Editora Unimontes, 2000. 
PAULA, H. A. Montes Claros sua história sua gente seus costumes - parte 1. Montes Claros: Unimontes, 2007. (Coleção Sesquicentenária v. 1).

PEREIRA, L. A. G. Planejamento e desenvolvimento: Logística de transportes e exportações na mesorregião norte de Minas Gerais, 2010. 172 f. Dissertação (Mestrado em Desenvolvimento Social) - Programa de Pós-Graduação em Desenvolvimento Social, UNIMONTES, Montes Claros, 2010.

PEREIRA, L. A. G.; LESSA, S. N. O primeiro centenário da infraestrutura ferroviária no Norte de Minas Gerais: processo de implantação, auge, crise e concessão. Revista Cerrados, v. 10, n. 01, p. 128-145, 31 dez. 2012.

PEZZOLO; D. B. Tecidos: História, tramas, tipos e usos. 5. ed. São Paulo: Ed. Senac, 2019.

SANTANENSE. A empresa - história. 2021. Disponível em: http://www.santanense.com.br/ empresa/historia.html. Acesso em: 01 de abr. 2021.

SARAIVA, L. A. S.; PIMENTA, S. M.; CORRÊA, M. L. Globalização e reestruturação produtiva: desafios à indústria têxtil brasileira. R. Adm., São Paulo, v.40, n.1, p.68-82, 2005. Disponível em: http://rausp.usp.br/wp-content/uploads/files/V4001068.pdf. Acesso em: 10 out. 2020.

SCHEFFER, M. R. Trends in textile markets and their implications for textile products and processes. In: SHISHOO, R. The Global Textile and Clothing Industry: Technological Advances and Future Challenges. Cambridge: Woodhead Publishing, 2012. 224 p.

SCHEFFER, Michiel. Internationalization of textile and clothing production. Tijdschnp voor Economische en Sociale Geograjie, [S./1.], v. 86, n. 5, p. 477-480, 1995.

SHISHOO, R. Introduction: trends in the global textile industry. In: SHISHOO, R. The Global Textile and Clothing Industry: Technological Advances and Future Challenges. Cambridge: Woodhead Publishing, 2012. 224 p.

SIlvA, B. Á.; DINIZ, D.; MOTA, I. P. B. Pirapora: Um Porto na História de Minas. Pirapora/MG. Interativa. 2000. 286p.

STEIN, S. Origens e Evolução da Indústria Têxtil no Brasil - 1850/1950. Rio de Janeiro: Campus, 1979.

SUZIGAN, W. Indústria Brasileira: Origem e Desenvolvimento. São Paulo: UNICAMP/Hucitec, 2000.

TRADE MAP. Estadísticas del comercio para el desarrollo internacional de las empresas

VAZ, A. M. A indústria têxtil em Minas Gerais. Revista de História, São Paulo, n. 111, p. 101$118,1977$. 